\title{
Elektron Sənəd Dövriyyəsi Sisteminin Yaradılması Məsələləri
}

\author{
Rəşid Oləkbərov ${ }^{1}$, Dinara Zeynalova ${ }^{2}$, Illkin Paşayev ${ }^{3}$ \\ ${ }^{1,2}$ AMEA İnformasiya Texnologiyaları İnstitutu, Bakı, Azərbaycan \\ ${ }^{3}$ Muğanbank ASC, Bak1, Azərbaycan \\ rashid@iit.ab.az ${ }^{1}$,dinalizade@gmail.com ${ }^{2}$,pashayev.ilkin@gmail.com ${ }^{3}$
}

\begin{abstract}
Xülasə- Məqalədə elektron sənəd dövriyyəsi sisteminin yaradılması və təsnifatı analiz olunmuşdur. Elektron Sənəd Dövriyyəsi (ESD) sistemi, kargüzarlığın təşkilində əsas məsələlərdən biri olan sənəd dövriyyəsi, sənədlərin daxil olması, yaradılması prosesindən başlayaraq sənədin icra olunması və ya göndərilməsi prosesinə qədər keçdiyi mərhələlər təhlil olunmuşdur. ESD sisteminin üstünlükləri göstərilmiş, onun strukturu, təhlükəsizlik məsələləri təhlil edilmişdir.
\end{abstract}

Açar sözlor - sanad dövriyyasi, elektron sanad, elektron sanad dövriyyssi sistemi, bulud texnologiyalart

\section{GİRIŞ}

İnformasiya cəmiyyətinin (İC) qurulması Azərbaycanda dövlət siyasətinin əsas prioritetlərindən biri hesab olunur. $\mathrm{Bu}$ siyasətin əsas istiqamətləri“" Azərbaycan Respublikasında informasiya comiyyətinin inkişafına dair 2014-2020-ci illər üçün Milli Strategiya"da müəyyən olunmuşdur. Eyni zamanda Azərbaycan Respublikası Prezidentinin 2012-ci il 4 sentyabr tarixli Fərmanı ilə təsdiq edilmiş "İdarələrarası elektron sənəd dövriyyəsi sistemi haqqında Osasnamə"də elektron sənəd dövriyyəsi sisteminin (ESDS) tətbiqinin və istifadəsinin normativ-hüquqi bazası və idarələrarası elektron sənəddövriyyəsi sisteminin yaradılması, idarə olunması və bu sistemdən istifadə qaydaları müəyyən edilmişdir.

Qəbul olunmuş proqram və sənədlərdə bir çox məsələlərlə yanaş1, dövlət orqanlarında elektron sənəd mübadiləsinin təşkili nəzərdə tutulur. Elektron sənəd dövriyyəsinin tətbiqi sənədlərinhazırlanması və emalına sərf olunan əməyin və vaxtın azalmasını, idarəçilikdə qərarlarınqəbul edilməsini, icra intizamının yüksəldilməsini və nəzarət mexanizminin sadələşməsini, əhaliyə xidmətin operativliyini, dövlət və özünüidarəetmə orqanlarının fəaliyyəti haqqındakı informasiya və xidmətlərə əlyetərliliyi, tabeçiliyində olan və digər təşkilatlarla əlaqələrin sürətləndirilməsini təmin etməyə imkan verir $[1,2]$.

\section{ELEKTRON SЭNӘD DÖVRIYYЭSİ SISTEMININ YARADILMASI MəSӘLӘSI}

Hal-hazırda dünyada təşkilat və müəsissələrdə elektron sənədlərin idarə olunmasında Docsvision, Directum, ELMA ECM+, Optima Work Flow, 1C və s. sistemlərdən geniş istifadə olunur. Qeyd edilən elektron sənəd dövriyyəsi sistemlərinin bir çoxüstünlukləri ilə bərabər, bəzi çatışmayan cəhətləridə (istifadəçi qovluqlarının olmaması, daxili e-poçt sisteminin olmamas1, sənədlərin avtomatik sistemə yüklənə bilməməsi, yeni jurnalların yaradılmasında olan çətinliklər, müxtəlif göstəricilər üzrə hesabatların aparılmaması,sənədlərin tammətn üzrə axtarışının olmaması və s.) vardır[3,4].

AMEA İnformasiya Texnologiyaları İnstitutunda deyilən catışmazlıqları aradan qaldırmaqla bulud texnologiyaları əsasında elektron sənəd dövriyyəsi sistemi yaradılmış və istismara verilmişdir.

Elektron sənəd dövriyyəsi sistemi kargüzarlığın təşkilində əsas məsələlərdən biri olan sənəd dövriyyəsi, təşkilatlarda sənədlərin alınması (kənar təşkilat və ya şəxslərdən) və ya yaradılması (daxili sənədləşmə, digər təşkilata göndərmək üçün hazırlanan sənədlər) prosesindən başlayaraq sənədin icra olunması və ya göndərilməsi prosesinə qədər keçdiyi bütün mərhələləri özündə əks etdirir[5].

ESDS müəssisə daxilində sənədlərin idarə olunması və sənədlərlə iş prosesini avtomatlaşdıran vahid bir sistemdir. Sistemin əsas məqsədi:

- sənədlərin hazırlanması, fayl şəklində bazada saxlanılması;

- müəssisə daxilində sənəd hərəkətinin təmin edilməsi;

- $\quad$ axtarıș sistemi;

- təhlükəsizliyin təmin edilməsi;

- hesabat və statistik məlumatların hazırlanması.

ESDS-nin əsas funksiyaları:

- təşkilata daxil olan və göndərilən sənədlərin sistemə daxil edilməsi;

- sənədin əslinin elektron formata salınıb sistemdə yadda saxlanılması;

- sənədin rəhbərliyə yönləndirilməsi, rəhbərlik tərəfindən sənədə dərkənar qoyulması və icraçılara yönləndirilməsi;

- icraçıların e-mail ünvanlarına xəbərdarlıq məktubunun göndərilməsi;

- icraçıların sənəd üzərində işləyib cavab məktubunu hazırlaması və sistemə yükləməsi;

- otraflı axtarış sistemi;

- sənədlərin icra prosesinin nəzarətdə saxlanılması;

- arxivin yaradılması. 


\section{ESDS-nin üstünlükləri:}

- ESDS-dən istifadə təşkilatda sənədlərin hazırlanması, izlənilməsi, saxlanılması, əldə olunması, göndərilməsi proseslərində tələb olunan resursları minimuma endirməyə imkan yaradır;

- $\quad$ sənəd hazırlamaq üçün sərf olunan müddəti minimuma endirir, sənədlərin vaxtında çatdırılmasını təmin edir;

- sənədlərin elektron formada saxlanılması fəlakət və digər risklərə qarşı sənədlərin təhlükəsizliyini təmin edir;

- sənədi hazırlama və saxlama xərcləri azalır;

- dəftərxana ləvazimatı xərclərinə, vaxta və iş qüvvəsinə qənaət olunur;

- sənəd axını sürətlənir və prosesin izlənməsinə imkan verir;

- icra zamanı gecikmələrin səbəbləri müəyyən edilir;

- kargüzarlıq fəaliyyəti təkmilləşir, sənədlərin qeydiyyatı, saxlanılması və sistemləşdirilməsini daha keyfiyyətli təmin edir və icra intizamını yüksəldir [6].

Sistemə daxil olan sənədlər 3 formada qruplaşdırlır:

1. Kənar təşkilatlardan daxil olan sənədlər (əmr, qərar, sərancam, məktub, telefonoqram və s.);

2. Göndərilən sənədlər (məktublar, cavab sənədləri, təkliflər və s.);

3. Təşkilat daxili sənədlər (protokollar, təqdimatlar, ərizələr, əmrlər və s.).

Müxtəlif mənbələrdən daxil olan sənəd ESDS-də qeydiyyata alınma prosesindən keçir. Sənədlər ESDS-də qeydiyyata alındiqda sənəd haqqında məlumatlar, yəni sənədi xarakteriza edən atributlar: sənədin tarixi, sənədin nömrəsi, onu göndərən təşkilat, sənədin tipi, daxilolma nömrəsi, daxilolma tarixi, icra müddəti, sənədin saxlanıldığı yer, açar sözlər və s. qeyd edilməklə fayl şəklində bazada yadda saxlanılır.

Bazada saxlanılan sənədin keçdiyi bütün proseslər (qeydlər, dəyişikliklər və s.) sistemdə qeyd olunur.İstənilən sənədi axtarıb tapmaq, yönləndirmək, qeyd yazmaq və s. kimi əməliyyatlar aparmaq mümkündür. Workflow sisteminin vasitəsilə əvvəlcədən daxil olunmuş sənəd növlərinə əsasən workflow şablonları yaradılır. ESD sistemində sənədlərin qəbulu və emal edilməsi üçün Workflow sistemindən istifadə edilir. Workflow sistemi sənədlər üzərində əməliyyatların tərtib edilmiş ardıcıllığa uyğun olaraq yerinə yetirilməsini təmin edən idarəetmə sistemidir. Bu sistemin köməyi ilə daxil olan sənədlərin növlərinə uyğun şablonlar yaradılır və bunun əsasında emal prosesini həyata keçirirlər. Nümunə olaraq emailvasitəsi ilə gələn sənəd növünün workflow-na baxaq: email vasitəsilə daxil olmuş sənədbazaya daxil olunur, kontent analizi aparılır. Kontentin analizi əsasında sənədin kimə göndəriləcəyi və hərəkət marşrutu müəyyən olunur. Sənədə nəzərət edən şöbə sistemdə sənədin emal prosesini, hans1 vəziyyətdə, hans1 mərhələdə olması haqq1nda məlumatları görür və bu sənədin gedəcəyi növbəti marşrutlar təyin edilir. Sənəd təyin olunmuş marşrut üzrə hərəkət edir və ən son göstərilmiş marşrutda (ünvanda) cavab hazırlanır və göndərmək tələb olunursa e-mail vasitəsi ilə cavab verilir.

AMEA-nın İnformasiya Texnologiya İnstitutunda yaradılmış elektron sənəd dövriyyəsi sisteminin iş prinsipi də bu cürdür. Nümunə üçün kənar təşkilatdan daxil olan sənədin emalı prosesinə baxaq:sənəd ümumi şöbəyə daxil olur, ümumi şöbənin əməkdaşı ESDS-də ona verilmiş istifadəçi adı və parol vasitəsilə sistemə daxil olaraq həmin sənədi sistemdə qeydiyyata alır. Qeydiyyat prosesində sənəd haqqında bütün məlumatlar sistemə daxil edilib yadda saxlanılır və direktora göndərilir. Direktor sənədlə tanı̧̧ olduqdan sonra icraçı(lar) təyin edir və dərkənar qoyaraq sənədi icraçı(lar)a yönləndirir. İcraçı(lar) sənəd üzərində işləyir(lər) və hazırlanan cavab və ya icra haqqında şərhi direktora göndərir(lər). Direktor sənədlə razılaşdıqda sənədi təsdiq edərək ümumi şöbəyə göndərir, əks halda sənəd yenidən icraçıya yönləndirilir, sənədlə iş başa çatana kimi proses davam edir. Ümumi şöbə razılaşdırılmış sənədi (cavab məktubunu) lazımi ünvana göndərə bilər və ya prosesi başa çatdıra bilər. Beləliklə, təşkilata daxil olan sənədin dövriyyə prosesi başa çatmış olur.

İnstitutdan göndərilən sənədin emal prosesi isə aşağıdakı kimidir:

Qəbul olunmuş şablonlar əsasında sənəd hazırlanır və ümumi şöbəyə göndərilir. Ümumi şöbə sənədi qəbul edir və lazım olan əməliyyatlar yerinə yetirildikdən sonra sənədi direktora göndərir. Direktor hazırlanan sənədlə tanış olur, əgər sənədlə razıdırsa imzalayır,əks halda sənəd dərkənarla ümumi şöbəyə göndərilir. Geri göndərilən sənəd üzərindəki dərkənara əsasən yenidən işlənilir. Tam hazırlanmış və rəhbərliklə razılaşdırılmış sənəd Ümumi şöbə əməkdaşı tərəfindən bazada saxlanılır və təyin olunan təşkilata göndərilir.

ESD sistemindən istifadə üçün hər bir əməkdaşın öz istifadəçi adı və paroluvardır. İstifadəçi bu istifadəçi adı və parol vasitəsi ilə ESDS-nə daxil olur.Sistemə daxil olduqdan sonra açılan pəncərədə əsas menyugörünür (şək.1)

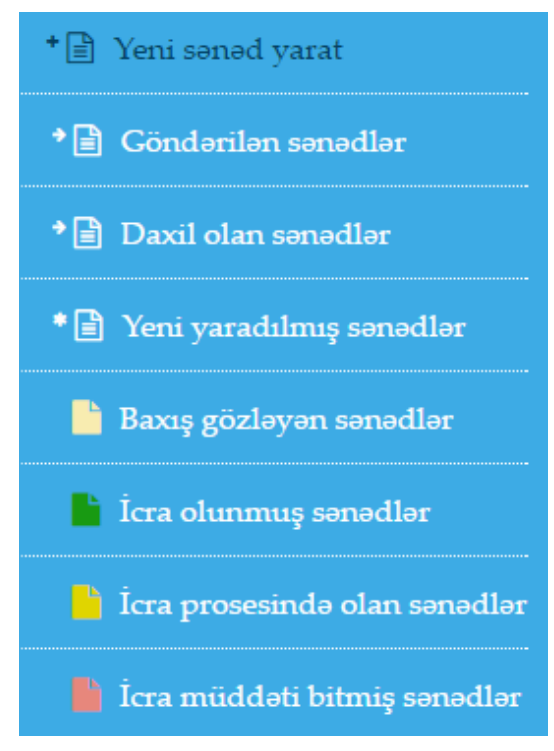

Şəkil 1. Sistemin əsas menyusu

Qeyd edilən menyuda istənilən emal prosesini seçməklə sənədüzərində əməliyyatlar aparmaq mümkündür. 


\section{ELEKTRON SONOD DÖVRIYYOSİ SISTEMININ TӘHLÜKӘSIZLLIK MӘSӘLӘLӘRI, NӘZARӘT, AXTARIŞ VӘ İSTIFADӘ PLATFORMASI}

ESDS-də təhlükəsizlik dedikdə istifadəçilərin hüquqları və sənədlər üzərində hansı əməliyyatlar apara biləcəyi qovluqlar (role) və sənədlərin fayl şəklində saxlanılması prinsip və mexanizmlər toplusu nəzərdə tutulur. İlk öncə istifadəçilərin qovluqlarıda yaradılır. Bu qovluqlar onlara ESD sistemindən istifadə etmək, hansı sənədləri görmək və ya sənədlə işləmək haqqında hüquqları özündə birləşdirir[7].

Sistemdə sənədlərin emalının, saxlanmasının və göndərilməsinin təhlükəsizliyinin təmin edilməsi üçün aşağıdakı kriteriyalardan istifadə edilmişdir:

- Sənədlərlə işləyərkən istifadəçilər yalnız özlərinin icraçı təyin olunduğu sənədləri görə bilər və özlərinin yaratdığı sənədləri görə və onlarla işləyə bilərlər; bilər;

- Direktor isə tabeliyində olan işçilərin sənədlərini görə

- Sənədin emalı prosesində iştirak etməyənşəxslər sənəd haqqinda məlumat əldə edə bilməz;

- Sənədlər fayl şəklində ayrıca fayl-serverdə saxlanılır. Həmin fayl-serverə giriş isə əlavə istifadəçi adı və parol vasitəsi ilə mümkündür;

- Ümumi sistemin və sənədlərin təhlükəsizliyini təmin etmək üçün müəyyən müddətdən bir bütün sistemin və faylların arxivi və backup versiyası hazırlanır;

- Yaradılan sistemdə sənədlərin həqiqiliyini və bütövlüyünü qorumaq üçün elektron imzadan istifadə edilir. Elektron imza göndərilən sənədlərə kənardan, icazəsiz müdaxilələrin qarşısını alır;

- Sistemdə hər hansı texniki problem yaranarsa və ya sistemin bir serverden digər serverə daşınması prosesi üçün bütöv sistemin baza və fayllarla birlikdə ehtiyatıalınır. Bu proses müəyyən müddətdən bir həyata keçirilir, ehtiyat surətlər (kopyalar) diskə və ya digər məlumat daşıyıcısına yazıla bilər.

Sənədlərin icrasını nəzarətdə saxlamaq üçün menyuda sənədlər müxtəlif qruplara(göndərilən sənədlər, daxil olan sənədlər, yeni yaradılmış sənədlər, baxış gözləyən sənədlər, icra olunmuş sənədlər, icra prosesində olan sənədlər, icra müddəti bitmiş sənədlər,sənədin son icra müddəti) bölünür (şəkil 1.). Menyuda hər bir bölməni aktivləşdirdikdə icra vəziyyətinə uyğun sənədlərin siyahısı göstərilir.Bundan əlavə sənədlər sistemə daxil edilərkən qeyd olunmuş icra müddətinə uyğun olaraq sənədin icraçısına və icraya nəzarət edən ümumi şöbə əməkdaşına e-mail vasitəsilə məlumat verilir. $\mathrm{Bu}$ da sənədlərin icrasına nəzarət etməyə imkan yaradır.Sistemə daxil edilən sənədlərin statusları daim yoxlanılır və sənəd öz statusuna uyğun olan qrupa göndərilir.

Sistemdə sənədlərin axtarılması “axtar" menyusu vasitəsilə həyata keçirilir (şək.2).

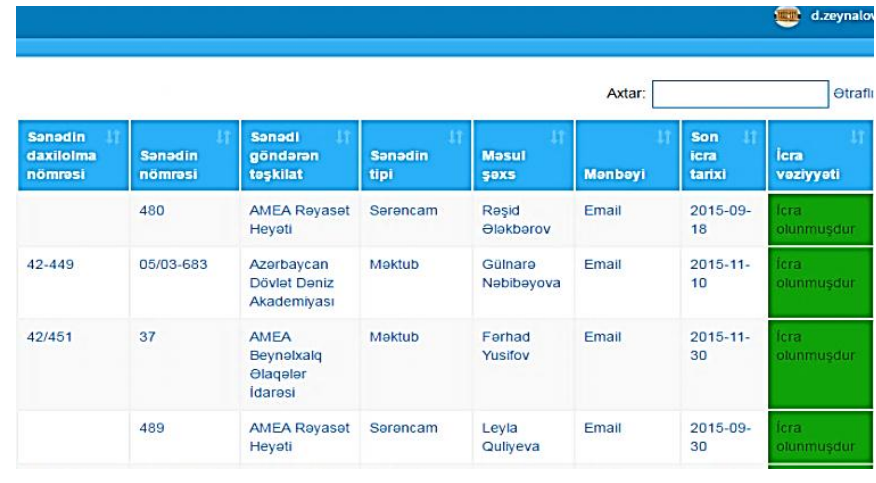

Şəkil 2.Sənədlərin sistemdə axtarılması

Menyuda "Otraflı" bölməsini aktivləşdirərək sənədlərin çoxsaylı göstəricilərinə əsasən (sənədin tarixi, sənədin daxil olma tarixi, sənədin nömrəsi, sənədin daxilolma nömrəsi, göndərən təşkilat, sənədin tipi, icra müddəti, məsul icraçı və s.) onların axtarışını təmin etmək olar.

ESD sistemində istifadə edilən sənədlər $M y S Q L$ idarəetmə sisteminin bazasında saxlanır və $P H P$ dili vasitəsi ilə yaradılmışdır. Bu sistemin yaradılmasında $P H P$ dili ilə yanaşı JavaScript vo s. müasir texnologiyalardan istifadə edilmişdir. Sistem Windows 2008 Server əməliyyat sisteminin fayl serverlərində yerləşdirilmişdir. ESD sistemində istənilən sayda istifadəçi və sənəd qeydiyyatdan keçirmək və yadda saxlamaq mümkündür. Sorğuların, axtarış sistemlərinin cəld, çevik çağrılması üçün sorğular optimizasiya edilir və sistemin cəldliyi təmin edilir. Sistemin MySQL bazasında yaradılması ona onlayn rejimdə çoxsaylı məlumatlarla işləmək imkanı verir. Məlumatlar cədvəllərdə saxlanılır. Funksionallıq üçün qaydalardan, müasir proqramlaşdırma üsullarından istifadə edilmişdir. ESDS-nin proqram təminatının yaradılmasında eyni zamanda veb texnologiyalarının imkanlarından istifadə edilmişdir. Sistem bulud texnologiyaları əsasında AzScienceNet elm kompüter şəbəkəsinin verilənlərin emal mərkəzinin serverlərində yerləşdirilmiş və $24 / 7$ müddətində istifadəçilər tərəfindən istismar edilir.

\section{NӘTİCə}

Məqalədə elektron sənəd dövriyyəsi sisteminin yaradılması və idarə olunması, proqram vasitələrinin təsnifatı analiz olunmuş, sistemin üstünlükləri göstərilmişdir. ESDS-nin müəssisə daxilində sənədlərin idarə olunması və sənədlərlə iş prosesini avtomatlaşdıran vahid bir sistem kimi məqsədi göstərilmişdir. Sənədin verilənlər bazasına daxil olunması üçünsənədi xarakteriza edən xüsusiyyətlər, daxil olan sənədin emal prosesi, sistemdə hərəkət prosesi təhlil edilmişdir. Elektron sənəd dövriyyəsi sisteminin təhlükəsizliyinin bir neçə əsas prinsipləri göstərilmişdir. Sistem bulud texnologiyaları əsasında AzScienceNet elm kompüter şəbəkəsinin verilənlərin emal mərkəzinin serverlərində yerləşdirilmişdir.

\section{ӘDӘBIYYАТ}

[1] Дж. Майкл, Д. Саттон, «Корпоративный документооборот. Принципы, технологии, методология внедрения». Б. Микроб 2002. $446 \mathrm{c}$.

[2] Г.Г. Асеев, «Электронный документооборот». Учебник., Киев, 2007. $500 \mathrm{c}$. 
[3] А. Гаевская, «Обзор систем электронного документо оборота», http://www.cfin.ru/ software/kis/edms.shtml

[4] «Обзор систем электронного документооборота», http://www.itweekly.ru/it-news/tech/105609.html

[5] М.С.Днепровский, Т.Я. Дубнищева, «Система электронного документооборота предприятия», II Международный студенческий научный вестник. 2016. №3, 64-65 с.

[6] К.О. Шрейтер, «Электронный документооборот возможности и преимущества», II Молодой ученный, 2005, №2, 52-55 с.

[7] А.Жеребенкова, «Документооборот на предприятии», 2005. 384 с.

Bu iş Azarbaycan Respublikasının Prezidenti yanında

Elmin İnkişafi Fondunun maliyya yardımı ilo yerino yetirilmişdir - Qrant № EIF-2014-9(24)-KETPL-14/02/1 